ERRATUM OPEN

\title{
Changes in initial COPD treatment choice over time and factors influencing prescribing decisions in UK primary care: a real-world study
}

Kevin Gruffydd-Jones, Guy Brusselle, Rupert Jones, Marc Miravitlles, Michael Baldwin, Rebecca Stewart, Anna Rigazio, Emily Davis, Dorothy L Keininger and David Price

npj Primary Care Respiratory Medicine (2017) 27, 17004; doi:10.1038/npjpcrm.2017.4; published online 8 June 2017

Correction to: npj Primary Care Respiratory Medicine (2016) 26, 16002. doi:10.1038/npjpcrm.2016.2; published online 25 February 2016

An error was introduced in the title of this paper at typesetting.

'Changes in initial COPD treatment choice over time and factors influencing prescribing decisions in UK primary care: in UK primary care: a real-world, retrospective, observational'

Should have been 'Changes in initial COPD treatment choice over time and factors influencing prescribing decisions in UK primary care: a real-world study'
An Erratum has been published and is appended to both the HTML and PDF versions of this paper. The error has been fixed in the paper.

(c) (i) $\odot$ This work is licensed under a Creative Commons Attributioncc) NonCommercial-NoDerivatives 4.0 International License. The images or other third party material in this article are included in the article's Creative Commons license, unless indicated otherwise in the credit line; if the material is not included under the Creative Commons license, users will need to obtain permission from the license holder to reproduce the material. To view a copy of this license, visit http:// creativecommons.org/licenses/by-nc-nd/4.0/

(c) The Author(s) 2017 